\title{
PENGARUH MODIFIKASI CROSSLINK TERHADAP KARAKTERISTIK TEPUNG UBI JALAR SAAT DIPANASKAN
}

\author{
Crosslink Modification Effect on the Characteristics of Sweet Potato Flour When Heated
}

\author{
Yustiawan, Heru Pitria Hastuti, Sahri Yanti* \\ Fakultas Teknologi Pertanian Universitas Teknologi Sumbawa \\ *email: sahri.yanti@uts.ac.id.
}

Diterima 2 Maret 2019 / Disetujui 22 Mei 2019

\begin{abstract}
Sweet potato is a plant that is easy to be cultivated and very potential to be processed into flour. But the quality is still low compared to other flour especially when heated. Because it is done to improve the quality especially when heated. Modification done crosslink using sodium tripolyphosphate reagent (STPP). The purpose of this study was to determine the effect of modified flour on flour characteristics when heated. Parameters used in this research are water absorption, Swelling Power, and flour solubility. The data processing used is RAL of 1 factor at the 0.05 level and further test using Duncan test. The results showed that the characteristics of flour modification is better than natural flour. The higher the concentration of STPP used, the water absorbency increases, the swelling power increases, and solubility decreases. Sweet potato flour has optimum absorption limit and optimal development on reaction process for 1 hour, and will decrease at longer reaction process. .
\end{abstract}

Key words: sweet potato, sweet potato flour, modified flour, crosslink modification, STPP

\section{ABSTRAK}

Ubi jalar merupakan tanaman yang mudah dibudidayakan dan berpotensi diolah menjadi tepung, namun kualitasnya masih rendah dibandingkan dengan tepung lainnya, khususnya saat dipanaskan. Oleh karena itu, perlu dilakukan upaya meningkatkan kualitas tepung ubi jalar terutama saat dipanaskan. Modifikasi dilakukan secara crosslink dengan pereaksi sodium tripolyfosfat (STPP). Tujuan penelitian ini adalah menentukan pengaruh modifikasi terhadap karakteristik tepung saat dipanaskan. Parameter yang digunakan pada penelitian ini adalah daya serap air, swelling power, dan solubillitas tepung. Pengolahan data menggunakan RAL faktorial pada taraf 0,05 dan uji lanjut menggunakan uji Duncan. Hasil penelitian menunjukan bahwa karateristik tepung modifikasi lebih baik daripada tepung alami. Semakin tinggi konsentrasi STPP, daya serap air meningkat, nilai swelling power meningkat, dan solubilitas menurun. Tepung ubi jalar memiliki batas optimum penyerapan serta pengembangan optimal pada reaksi selama 1 jam dengan konsenrasi STTP 3\%, serta menurun pada reaksi yang lebih lama.

Kata kunci: ubi jalar, tepung ubi jalar, modifikasi pati, modifikasi crosslink, STPP

\section{PENDAHULUAN}

Salah satu potensi pengolahan tanaman ubi jalar masa mendatang adalah diolah menjadi tepung (Honestin 2007). Olahan ubi jalar menjadi tepung merupakan salah satu upaya pengawetan dari ubi jalar. Nur Richana dalam Kristiyani (2012), mengatakan bahwa tepung ubi jalar merupakan produk setengah jadi sebagai bahan baku industri makanan dan mempunyai daya simpan yang lebih lama. Selain itu, Smith dalam Honestin (2007), juga menegaskan bahwa tepung dipilih sebagai olahan pertama ubi jalar karena pati alamiah sangat terbatas penggunaannya. Pemanfaatan tepung ubi jalar di Indonesia terus dikembangkan yaitu sebagai bahan substitusi dalam pembuatan produk seperti makanan bayi, food powder, mie, roti, dan pudding (Widyasaputra 2013). Meskipun pengolahan tepung ubi jalar sudah mampu mengawetkan pati, karakteristik fisik tepung ubi jalar terutama ubi jalar putih masih kurang baik. Hal tersebut karena pola pengembangan terbatas saat pemanasan, cenderung mudah teretrogradasi dan daya serapnya terhadap air yang rendah (Widyasaputra 2013). Keadaan seperti inilah yang menyebabkan aplikasi olahan tepung ubi jalar memiliki kualitas dan daya saing tergolong rendah dipasaran.

Mengingat kandungan gizi tepung ubi jalar yang cukup tinggi, sehingga perlu dilakukan modifikasi karateristik tepung secara crosslink, untuk mencari karakteristik tepung yang terbaik saat dipanaskan. Tujuan 
Versi Online:

http://www.profood.unram.ac.id/index.php/profood e-ISSN: 2443-3446

penelitian adalah untuk mengetahui perlakuan yang menghasilkan tepung ubi jalar dengan karakteristik terbaik.

\section{BAHAN DAN METODE}

Penelitian dilaksanakan dari tanggal 24 Maret 2016 hingga 20 Juni 2017 di Laboratorium Pangan Universitas Teknologi Sumbawa.

Alat - alat yang digunakan yaitu: Baskom, Pisau, Blender, Loyang, Ayakan, Oven, Hot Plate Stireer, Timbangan Bahan, Gelas Kimia, Pipet, Loyang, Gelas Kimia 500 mL, Gelas Kimia 100 mL, Gelas Kimia 50 mL,Alat Pemutar YJ 250, Tabung Ukur 100 mL, Wadah Sentrifius Volume $45 \mathrm{~mL}$, Kain Saring, dan Timbangan Analitik. Bahan-bahan yang digunakan adalah umbi tanaman ubi Jalar, air, pereaksi crosslink(STPP), larutan dan aquades.

\section{Preparasi Sempel}

Proses penepungan ubi jalar menurut Honestin (2007), diawali dengan pengupasan, selanjutnya diiris tipis - tipis. Kemudian hasil pengirisan dihancurkan menggunakan blender hingga membentuk adonan/ pasta. Adonan ubi jalar dikeringkan dibawah sinar matahari selama 12 - 36 jam. Selanjutnya dihancurkan lalu diayak agar tepung ubi jalar lebih homogen.

\section{Tepung Modifikasi Crosslink (Retnaningtyas, 2014)}

Tepung ubi jalar sebanyak $150 \mathrm{~g}$ dilarutkan dalam $450 \mathrm{~mL}$ aquades. Dimasukan kedalam gelas kimia $500 \mathrm{~mL}$ dan ditambahkan peraksi crosslink (STPP) dengan konsentrasi (1\%, $2 \%$, dan $3 \%)$. Kemudian adonan distirrer selama 30 menit, 1 jam, dan1,5 Jam, proses ini akan berakhir dengan menghasilkan endapan tepung. Endapan tepung selanjutnya disaring dan dicuci bersih dengan aquades $100 \mathrm{~mL}$ sebanyak 3 kali. Selanjutnya dikeringkan pada suhu $50^{\circ} \mathrm{C}-60^{\circ} \mathrm{C}$ selama 6 jam.selanjutnya digiling dan diayak mengunakan ayakan (80 mesh).

\section{Swelling Power dan Solubilitas (Retnaningtyas, 2014)}

$0,5 \mathrm{~g}$ sampel dilarutkan dengan $15 \mathrm{~mL}$ air dan dimasukan kedalam tabung sentrifius
ISSN: 2443-1095

$25 \mathrm{~mL}$. Selanjutnya tabung dipanaskan pada suhu $85^{\circ} \mathrm{C}$ selama 30 menit kemudian diaduk agar tidak mengendap. Pasta selanjutnya disentrifius pada kecepatan $2250 \mathrm{rpm}$ selama 20 menit. Filtrat dipisahkan dari endapan yang terbentuk. Filtrat diuapkan pada suhu $100^{\circ} \mathrm{C}$ selama 8 jam dan ditimbang. Perbandingan berat supernatan kering dengan berat sampel padatan kering adalah solubilitas (\%). Endapan ditimbang dan selanjutnya swelling power diukur berdasarkan rasio perbandingan berat endapan terhadap berat sampel padatan keringnya $(\mathrm{g} / \mathrm{g})$.

\section{Daya Serap Air (Dewi, 2008)}

$0,5 \mathrm{~g}$ sempel direndam didalam $10 \mathrm{~mL}$ air hangat selama 5 menit. Setelah itu sempel diangkat dan ditiriskan. Air perendam kemudian ditimbang kembali.

\section{Rancangan Penelitian}

Rancangan percobaan yang digunakan adalah rancangan acak lengkap dengan 2 faktor pengaruh yaitu konsentrasi pereaksi STPP $(1 \%, 2 \%$, dan 3\%) dan lama proses reaksi (30 menit; 1 jam; dan 1,5 jam) yang diberikan pada tepung ubi jalar dengan masing-masing 3 kali ulangan yang akan dianalisa menggunakan uji ANOVA dengan $a=5 \%$.

Tabel 1. Rancangan Penelitian

\begin{tabular}{|c|c|c|c|c|}
\hline \multicolumn{2}{|c|}{ Perlakuan } & \multicolumn{3}{|c|}{$\begin{array}{l}\text { Variasi Konsentrasi } \\
\text { STPP }\end{array}$} \\
\hline \multirow{10}{*}{$\begin{array}{l}\text { Variasi } \\
\text { Lama } \\
\text { Proses } \\
\text { Reaksi }\end{array}$} & & $1 \%$ & $2 \%$ & $3 \%$ \\
\hline & \multirow{3}{*}{$\begin{array}{c}30 \\
\text { menit }\end{array}$} & P1u1 & P2u1 & P3u1 \\
\hline & & P1u2 & P2u2 & P3u2 \\
\hline & & P1u3 & P2u3 & P3u3 \\
\hline & \multirow[t]{3}{*}{1 jam } & P4u1 & P5u1 & P6u1 \\
\hline & & P4u2 & P5u2 & P6u2 \\
\hline & & P4u3 & P5u3 & P6u3 \\
\hline & \multirow[t]{3}{*}{$1,5 \mathrm{jam}$} & P7u1 & P8u1 & P9u1 \\
\hline & & P7u2 & P8u2 & P9u2 \\
\hline & & P1u3 & P8u3 & P9u3 \\
\hline
\end{tabular}

$$
\begin{aligned}
& \text { Ket : } \quad \begin{array}{l}
\mathrm{U} \\
\text { : : Perlakuan Ke- }
\end{array} \\
& \text { C : sempel control }
\end{aligned}
$$


Apabila hasilnya menunjukan beda nyata dari pengaruh kombinasi kedua faktor, maka dilanjutkan uji lanjut Duncan pada taraf nyata $5 \%, 3$ kali ulangan dengan software SPSS.

\section{HASIL DAN PEMBAHASAN}

\section{Tepung Ubi jalar}

Ubi jalar yang digunakan berasal dari pasar seketeng (pasar terbesar di Kecamatan Sumbawa, Kabupaten Sumbawa Besar). Honestin (2007) menjelaskan ada 2 cara membuat tepung ubi jalar yaitu kering dan basah. Pembuatan tepung dengan cara kering: ubi jalar diiris tipis lalu dikeringkan (chips/sawut kering) kemudian ditepungkan, Sedangkan cara basah yaitu ubi jalar diparut atau dibuat pasta lalu dikeringkan dan kemudian ditepungkan. Tepung ubi jalar dalam penelitian ini dibuat dengan cara basah, karena proses pengolahannya relatif lebih singkat.

Pembuatan pasta ini dapat dilakukan dengan berbagai metode seperti menurut Honestin (2007) pembuatan pasta ubi jalar dilakukan menggunakan proses pemarutan.

Pengeringan pasta dapat dilakukan dengan metode seperti menurut Nur Richana dalam Kristiyani (2012) mengunakan metode oven dengan suhu $60^{\circ} \mathrm{C}$ selama 10 jam, serta menurut Widhaswari (2014) mengunakan metode menggunakan cabinet dryer pada suhu $60{ }^{\circ} \mathrm{C}$ selama 12 jam. Dalam penelitian ini pengeringan pasta menggunakan matahari. Pengeringan matahari dipilih karena memiliki keuntungan seperti proses pengeringan bahan bisa dilakukan secara sekaligus, artinya pada pengeringan matahari (penjemuran) tidak ada kapasitas batas maksimum bahan.

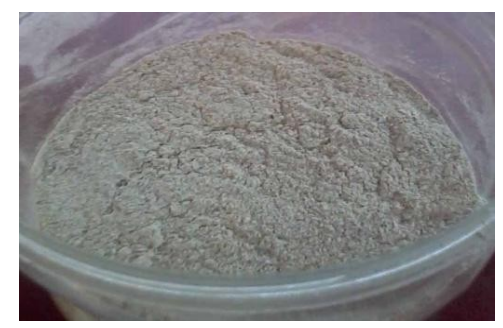

Gambar 1. Tepung Ubi Jalar Hasil Modifikasi

Pengeringan matahari menghasilkan kadar air bahan yang relatif seragam, sebab dilakukan sekaligus terhadap semua bahan.
ISSN: 2443-1095

Selanjutnya finishing berupa penumbukan dan pengayakan. Penumbukan bertujuan mengecilkan partikel adonan pasta ubi yang telah dikeringkan hingga berbentuk tepung. Sedangkan proses pengayakan untuk mendapatkan partikel tepung yang homogen.

Dari Gambar 1 terlihat tepung ubi jalar yang dihasilkan ini memiliki warna yang agak kecoklatan. Tepung tersebut telah mengalami reaksi pencoklatan (browning) yang terjadi secara alami. Proses pencoklatan disebabkan oleh aktivitas enzimfenolase dalam reaksi oksidasi senyawa fenol, yang secara alami terdapat pada umbi tanaman ubi jalar (Honestin, 2007).

Pada proses pembuatan tepung ubi jalar yang berkualitas sebaiknya perlu dilakukan tindakan antisipasi terhadap reaksi pencoklatan yang dapat terjadi secara alami.

Honestin (2007) mengatakan solusinya adalah perendaman ubi didalam larutan Metabisulfit $0,3 \%$. Sedangkan menurut Widhaswari (2014), dan Lensun dkk. (2013) solusinya dengan metode pengukusan umbi ubi jalar sampai setengah matang yaitu suhu \pm 100 ${ }^{\circ} \mathrm{C}$, selama \pm 5 menit. Proses selanjutnya adalah proses modifikasi crosslink.

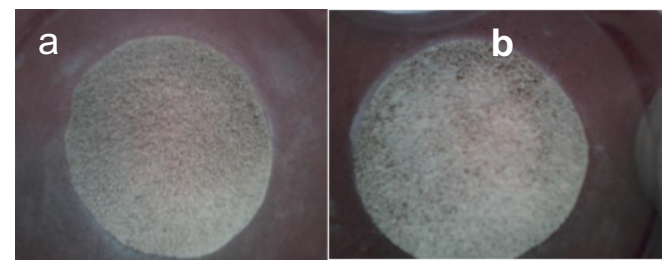

Gambar 2. (a) Tepung modifikasi crosslink (b) Tepung kontrol (alami)

\section{Daya Serap Air}

Modifikasi

crosslink dapat meningkatkan daya serap air tepung. Tepung ubi jalar alami (kontrol) memiliki kemampuan menyerap air hanya $20 \%$, sedangkan untuk tepung yang dimodifikasi secara crosslink memiliki kemampuan menyerap air lebih besar yaitu $20-60 \%$.

Hasil analisa data dengan uji anova dengan taraf $(a=0,05)$ menunjukkan faktor perlakuan yang diberikan memiliki pengaruh sebab nilai $\rho$-value dari masing - masing perlakuan yang dihasilkan dari uji ANOVA diatas lebih kecil dari pada nilai taraf yang 
Versi Online:

http://www.profood.unram.ac.id/index.php/profood e-ISSN: 2443-3446

digunakan ( $a=0,05)$, yaitu perlakuan variasi konsentrasi STPP sebesar 0,000 dan variasi perlakuan lama proses reaksi sebesar 0,016. Selanjutnya dilakukan uji Duncan, bertujuan mengetahui sempel yang memiliki daya serap air terbaik dan sempel yang memiliki daya serap air hampir sama.

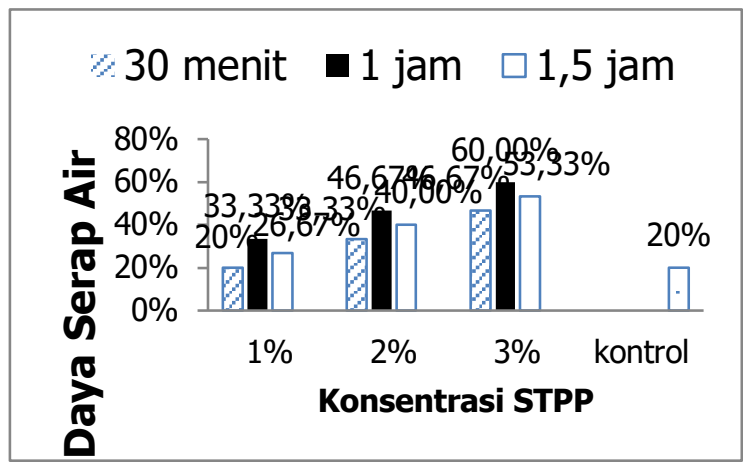

Gambar 3. Grafik Analisis Daya Serap Air

Hasil uji Duncan konsentrasi STPP penghasil daya serap air dengan rata - rata yaitu $0 \%=20,00 \mathrm{a} ; 1 \%=28,89 \mathrm{ab} ; 2 \%=$ $40,00 \mathrm{~b} ; 3 \%=53,33 \mathrm{c}$. Berdasarkan hasil uji Duncan tersebut diketahui bahwa variasi konsentrasi pereaksi crosslink (STPP) memang memiliki pengaruh terhadap kemampuan menyerap air. Pengunaan pereaksi STPP yang semakin banyak mampu meningkatkan daya serap air tepung ubi jalar, penambahan STPP dengan konsentrasi 3\% yang menunjukan daya serap air paling tinggi.

Pada proses pemanasan, molekul pati terhidrolisis sehingga hidrogen molekul penyusun pati akan putus.

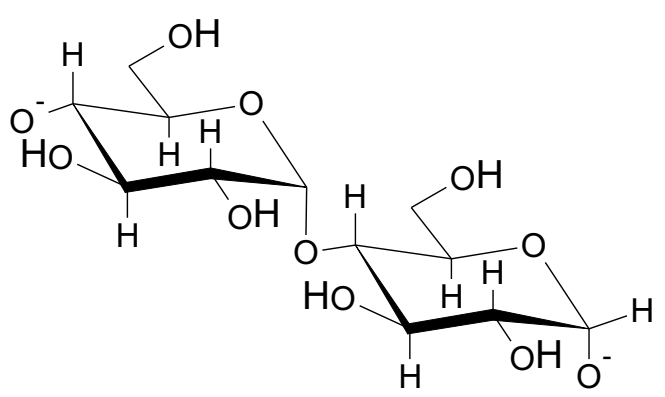

Gambar 4. Molekul pati setelah pemanasan

Hidrolisis pati akibat pemanasan berdampakmolekul penyusun pati menjadi tidak stabil, menyisakan molekul $\left(\mathrm{OH}^{-}\right)$yang tidak stabil (Amin 2013). Keadaan molekul
ISSN: 2443-1095

yang tidak stabil, menyebabkan terbentuknya ikatan baru dengan senyawa yang juga bermuatan tidak stabil, salah satunya dengan muatan positif (Setiowati, 2010).

Fosfat dari sodium tripolyposfat memiliki beberapa atom yang bersifat tidak stabil, memilki pasangan electron bebas pada atom $\mathrm{O}$. Selanjutnya molekul penyusun pati akan berikatan dengan molekul senyawa fosfat untuk membentuk ikatan yang lebih stabil (Amin 2013). Ikatan fosfat juga akan menjadi penghubung molekul penyusun pati yang satu dengan lainnya atau menggantikan fungsi ikatan hidrogen. Sehingga rantai molekul pati akan menjadi semakin panjang

Menurut Amin (2013), STPP merupakan salah satu senyawa yang mengandung fosfat yang dapat menggantikan ikatan hidrogen sebagai jembatan penghubung antar amilum pada pati. Salah satu kelebihan dari molekul amilum dengan ikatan fosfat adalah mampu mempertahankan ikatan dengan waktu yang relatif lebih lama dibandingkan dengan molekul terikat ikatan hidrogen terutama saat pemanasan (Amin 2013). STPP juga merupakan salah satu senyawa fosfat yang bersifat polar (mudah mengikat air), sehingga air dapat masuk ke dalam granula pati (Retnaningtyas 2014, Widyasaputra 2013). Semakin banyak senyawa fosfat yang diberikan maka akan semakin banyak terjadi ikatan silang pati fosfat, serta semakin banyak air yang terpenetrasi ke dalam granula pati.

Penambahan senyawa fosfat juga akan mempengaruhi karaktristik fisik molekul pati yaitu meningkatkan jumlah pororsitas bahan. Porositas adalah jumlah pori-pori pada bahan. Pori-pori bahan inilah yang nantinya akan diisi oleh air. Semakin banyak porositas atau poripori pada bahan maka akan semakin banyak bahan tersebut menyerap air. Ditegaskan oleh Hendry (2007), peningkatan jumlah porositas suatu bahan salah satunya dilakukan secara kimiawi yaitu dengan merendam bahan didalam larutan yang mengandung senyawa fosfat. Porositas bahan berbanding lurus dengan konsentrasi senyawa fosfat. Marta dkk (2016) menyebutkan bahwa pengunaan STPP ini akan menyebabkan semakin tinggi tingkat 
gelatinisasi suatu bahan, dengan demikian, maka akan semakin tinggi pula porositasnya.

Penambahan senyawa fosfat menunjukan pengaruh yang berbanding lurus dengan konsentrasi pereaksi yang digunakan, artinya semakin besar konsentrasi senyawa fosfat yang digunakan maka daya serap air tepung modifikasi akan semakin besar begitu pula sebaliknya.

Sama halnya dengan variasi STP, Hasil penelitian menunjukan secara keseluruhan lama proses reaksi berpengaruh terhadap daya serap air. Tepung yang direaksikan selama 30 menit dan 1 jam menunjukan sebuah peningkatan daya serap air, akan tetapi untuk tepung yang direaksikan selama 1,5 jam menunjukan penurunan. Hal tersebut karena granula pati telah melampaui batas hidrasi (penyerapan air) yang maksimal.

Lama proses rekasi yang diberikan menunjukan pengaruh yang berbeda pada setiap perlakuan yang diberikan. Tepung yang tidak direaksikan dengan senyawa fosfat (STPP) memiliki daya serap air paling rendah dengan rata-rata sebesar $20 \%$. Adanya proses modifikasi yang diberikan menunjukan peningkatan daya serap air tepung. Tepung yang direaksikan selama 30 menit dapat meningkatkan daya serap air menjadi 33,33\% serta terus mengalami peningkatan saat direaksikan dengan waktu 1 jam dengan rata rata sebesar $48,89 \%$

Peningkatan daya serap air ini di sebabkan oleh semakin banyaknya jumlah senyawa fosfat yang berikatan dengan penyusun granula pati pada partikel tepung. Akan tetapi pada tepung yang direaksikan selama 1,5 jam mampu menyerap air dengan rata - rata sebesar $40 \%$. Artinya pada reaksi selama 1,5 jam menunjukan adanya penurunan daya serap air tepung.Proses perendaman yang terlalu lama ini dapat menyebabkan kerusakan pada molekul penyusun granula pati yang menyebabkan air terlepas berkurangnya kandungan air pada partikel tepung.

Hal ini sesuai dengan hasil penelitian hee-Joung An, dalam Pudjihastuti (2010), melaporkan bahwa daya serap air dipengaruhi oleh lama waktu perendaman yang diberikan. Semakin lama perendaman, semakin lama
ISSN: 2443-1095

proses hidrolisisnya, sehingga rantai pati tereduksi atau terputus. Komponen penyusun granula pati tersebut akan cendrung pecah dan mengakibatkan kemampuan mengikat serta menyerap akan air kembali menurun (Retnaningtyas, 2014). Perendaman yang terlalu lama dapat meningkatkan daya serap air secara terus menerus oleh granula, hingga mencapai volume hidrasi maksimum (Amin, 2013).

Daya serap air dalam tepung ubi juga dipengaruhi oleh kandungan proteinnya, menurut Kilara dalam Tryono (2010), dengan jumlah dan tipe gugus-gugus polar yang berbeda maka kemampuan protein dalam menyerap air pun berbeda. Tepung ubi jalar mengandung protein sekitar 2,79\% dari 100 gram bahan ubi jalar (Naim 2016), selain protein, erat dalam tepung juga mempengaruhi daya serap air. Richana (2004) menjelaskan daya serap air suatu bahan dipengaruhi oleh keberadaan serat, karena sifat alami serat yang mudah menyerap air. Tepung ubi jalar memiliki kadar serat sebanyak $4,72 \%$ dari total $100 \mathrm{~g}$ bahan. Tepung yang mengandung amilosa yang relatif tinggi akan meningkatkan daya serap air tepung tersebut (Widyasaputra 2013). Komponen penyusun pati pada tepung ini dengan kadar amilosa lebih rendah dibandingkan dengan kadar amilopektin. Menurut Swinkels dalam Honestin (2007), Granula pati ubi jalar berbentuk polygonal dengan kandungan amilosa dan amilopektin berturut-turut adalah $20 \%$ dan $80 \%$. Semakin banyak kandungan protein serat pada tepung maka tepung tersebut semakin menyerap air.

\section{Swelling Power}

Hasil penelitian menunjukan modifikasi crosslink meningkatkan kemampuan pengembangan (swelling power) tepung. Untuk membuktikan pengaruh antara perlakuan yang diberikan, maka data hasil penelitian dianalisa menggunakan uji ANOVA $(a=0,05)$ menggunakan software SPSS. Hasilnya menunjukkan faktor perlakuan yang diberikan mempengaruhi kemampuan mengembang sempel.

Nilai $\rho$-value dari masing - masing perlakuan yang dihasilkan dari uji ANOVA 
Versi Online:

http://www.profood.unram.ac.id/index.php/profood e-ISSN: 2443-3446

diatas lebih kecil daripada nilai taraf yang digunakan yaitu $\mathrm{a}=0,05$ yaitu konsentrasi STPP sebesar 0,000 dan perlakuan lama proses sebesar 0,000 . Situasi seperti ini menjelaskan bahwa masing-masing perlakuan yang diberikan menunjukan ada hasil yang berbeda nyata dengan hasil lainnya. Selain itu dari hasil uji anova diatas juga diketahui bahwa interaksi antara kedua perlakuan yang diberikan ternyata justru menghasilkan nilai tidak berbeda nyata dengan hasil lainnya. Sebab nilai $\rho$ value yang dihasilkan oleh interaksi kedua perlakuan cendrung lebih besar dari taraf yang digunakan. Berdasarkan hasil penelitian yang telah dilakukan, diketahui bahwa ternyata variasi konsentrasi senyawa phosfat yang digunakan memiliki pengaruh terhadap kemampuan mengembang (swelling power) sempel tepung.

Perbandingan nilai Swelling Power dari rata-rata perlakuan tepung Kontrol $(0 \%) 0,67$ : tepung STPP $1 \%, 0,84$. Hal yang sama juga dilaporkan oleh Retnaningtyas (2014) yaitu perbandingan antara nilai Swelling Power tepung alami $(4,34 \%)$ : tepung modifikasi $(4,61 \%)$. Setiyowati (2010) juga melaporkan bahwa STPP dapat meningkatkan volume pengembangan pada beras.

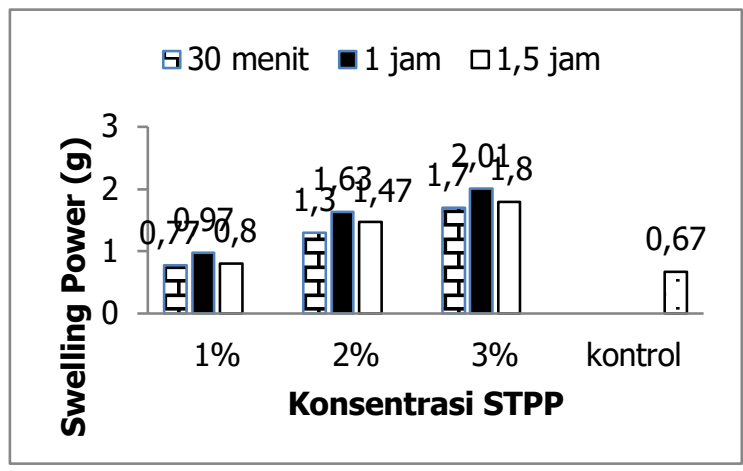

Gambar 5. Grafik Analisis Swelling Power

Peningkatan nilai Swelling Power dari tepung hasil modifikasi STPP disebabkan oleh kelebihan dari senyawa fosfat. Hal ini sesuai dengan pendapat Zapsalis et al dan Liu et al didalam Rohajatien (2010) menjelaskan hubungan antara pereaksi Crosslink dari kelompok fosfat dengan kemampuan meningkatnya kekuatan mengembangnya produk pati, yaitu dengan adanya gugus positif
ISSN: 2443-1095

fosfat pada proses fosforilasi, menyebabkan penghubung ikatan antar rantai pati yang berdekatan, hingga menyebabkan pati lebih kuat dalam mengembang.

Meningkatnya swelling power disebabkan oleh adanya senyawa yang mendorong granula pati, sehingga terjadi pembengkakan granula (Susanti, 2014). Menurut Retnaningtyas dkk (2014), STPP akan meningkatkan nilai swelling power sebab memiliki gugus fosfat yang bersifat polar. Aziz dalam Kalsum dkk (2013) menambahkan, masuknya air ke dalam molukul tepung menyebabkan ikatan antarmolekul tepung akan melemah sehingga nilai swellingpower tepung lebih tinggi daripada tepung alami. Zapsalis et al dalam Rohajatien (2010), juga menjelaskan bahwa peningkatan kadar fosfat mengakibatkan menurunnya ikatan intermolekuler sehingga nilai swelling power akan cendrung meningkat.

Menurut Murillo dalam Amin (2013), juga melaporkan Semakin tinggi kadar amilosa maka nilai pengembangan volume akan semakin tinggi, hal ini dikarenakan kadar amilosa yang tinggi akan menyerap air lebih banyak sehingga pengembangan volume akan semakin besar.

Swelling power tepung modifikasi mengalami peningkatan secara maksimal yaitu saat direaksikan selama 1 jam, sedangkan saat tepung direaksikan dengan waktu yang lebih lama menghasilkan Swelling Power yang cendrung menurun. Kejadian ini disebabkan oleh kemampuan optimal kandungan amilum yang terdapat pada tepung untuk menyerap air. Tepung mengembang setelah mencapai batas optimalnya, dan ini terjadi pada proses perendaman selama 1 jam.

Proses reaksi yang lama saat perendaman tidak terlalu baik untuk kekuatan mengembang. Hal ini di sebabkan oleh semakin lama waktu yang diberikan maka akan semakin tinggi volume air yang masuk ke dalam granula pati. Hal tersebut terlihat pada proses reaksi selama 1,5 jam yang cendrung mengalami penurunan pengembangan. Granula pati telah mencapai pengembangan maksimum pada saat direaksi selama 1 jam, serta granula pati akan cendrung pecah jika direaksikan lagi dengan 
waktu yang lebih lama. Retnaningtyas dkk (2014) juga melaporkan bahwa perendaman terlalu lama juga akan menurunkan swelling power pati.

Jika granula pati akan terus mengembang, viskositas meningkat, maka volume hidrasi maksimum dapat dicapai oleh granula tepung. Ketika granula pati telah terhidrasi, maka molekul-molekul amilosa akan pecah, sehingga menyebar ke media luar yaitu air perendaman (Amin 2013). Budiyati dkk (2016) solubilitas yang relative tinggi, disebabkan hilangannya kemampuannya pati untuk memegang/menyerap air sehingga swelling powernya menurun dan sebaliknya akan meningkatkan solubilitas (kelarutan) pati.

\section{Solubilitas (kelarutan)}

Berdasarkan hasil penelitian, diketahui bahwa proses modifikasi tepung ternyata memiliki pengaruh terhadap hasil uji solubilitas tepung. Adanya modifikasi menyebabkan solubilitas tepung menurun yaitu tepung kontrol atau tepung alami diketahui memiliki solubilitas sebesar $46,6 \%$, sedangkan tepung modifikasi memiliki daya solubilitas sebesar 6,7 $-40 \%$

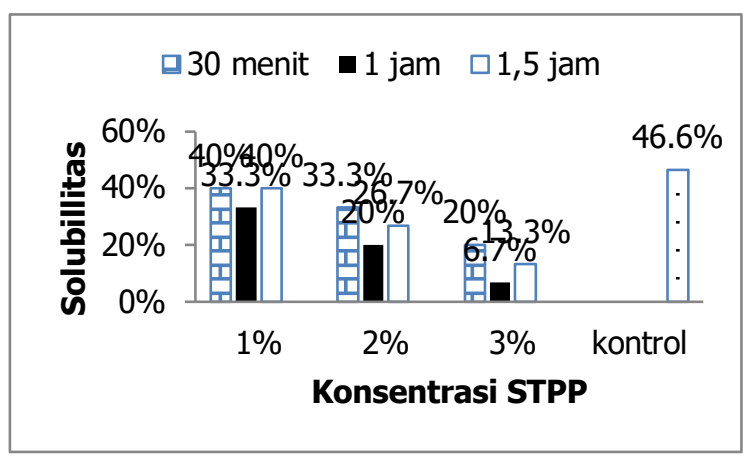

Gambar 6. Grafik Analisis Solubilitas

Berdasarkan hasil uji ANOVA diketahui bahwa kedua perlakuan tersebut memiliki pengaruh terhadap hasil solubillitas yang didapatkan dari sempel. Hal ini dibuktikan oleh nilai $\rho$ value yang dihasilkan dari setiap perlakuan cendrung lebih kecil dari nilai taraf yang digunakan $(0,05)$ yaitu variasi konsentrasi sebesar 0,000 dan perlakuan variasi lama proses reaksi sebesar 0,049 . situasi seperti ini menjelaskan bahwa masing-masing perlakuan yang diberikan memberikan hasil ada yang
ISSN: 2443-1095

berbeda nyata dengan hasil lainnya. Selain itu dari hasil uji anova juga diketahui bahwa intraksi antara kedua perlakuan yang diberikan ternyata menghasilkan nilai tidak berbeda nyata dengan hasil lainnya. Sebab nilai $\rho$-value yang dihasilkan oleh intraksi kedua perlakuan cendrung lebih besar dari taraf yang digunakan. Selanjutnya dengan adanya hasil yang menunjukan adanya hasil yang berbeda nyata inilah yang mengharuskan untuk dilakukan uji lanjut yaitu menggunakan uji Duncan

Berdasarkan hasil uji anova diketahui bahwa ternyata variasi konsentrasi STPP memiliki pengaruh terhadap hasil daya Solubilitas sempel yang dihasilkan. hal ini dibuktikan oleh nilai $\rho$-value yang dihasilkan saat uji ANOVA memiliki nilai yang lebih kecil dari nilai taraf yang digunakan yaitu 0,05. Maka dilakukan uji lanjutan (uji Duncan) dengan tujuan untuk mengetahui tingkat pengaruh yang dapat disimpulkan dari tingkat kesamaan hasil solubilitas sempel. Hasil uji lanjut duncan diketahui bahwa masing-masing variasi konsentrasi memberikan pengaruh yang berbeda-beda pada hasil solubilitas tepung. Dari hasil analisa juga diketahui bahwa solubilitas mengalami penurunan seiring semakin tinggi konsentrasi STPP yang ditambahkan. Hal yang sama dilaporkan oleh Retnaningtyas dkk (2014), yang menjelaskan bahwa semakin tinggi konsentrasi STPP yang digunakan akan menyebabkan solubillitas/ kelarutan tepung akan semakin menurun. Hal ini dibuktikan berdasarkan hasil penelitiannya yang mengaplikasikan modifikasi menggunakan STPP pada tepung ubi jalar, adapun hasilnya berupa pada konsentrasi STPP 0,5\% = 5,8\% dan pada konsentrasi $1,0 \%=1,6 \%$ yang sama-sama direkasikan selama 1 jam.

Menurut Retnaningtyas dkk (2014), yang menjelaskan bahwa memang semakin tinggi konsentrasi STPP yang digunakan akan menyebabkan solubillitas/ kelarutan tepung akan semakin menurun. Penambahan STPP ini akan menyebabkan pati berikatan dengan molekul fosfat membentuk ikatan silang pati fosfat. Ikatan senyawa fosfat dapat menurunkan solubillitas. Ikatan silang yang terbentuk menyebabkan ikatan-ikatan kovalen 
diantara molekul pati termodifikasi lebih kuat dibandingkan dengan pati alami yang hanya terdiri dari ikatan hidrogen, sehingga memungkinkan pati termodifikasi yang larut air lebih sedikit daripada pasta pati alami (Armayuni 2015), yang berdampak pada peningkatan berat molekul pati (Retnaningtyas 2014). Ikatan pati fosfat ini akan mengembang dengan kapasitas yang lebih besar saat pati dipanaskan. pati yang memiliki daya mengembang yang tinggi akan meningkatnya derajat subtitusi, dan menurunkan solubility karena sebagaian besar pati sudah mengembang menjadi pasta pati, dan hanya meninggalkan sedikit pati yang masih dapat larut bersama air (Armayuni 2015).

Menurut Chang et al dalam Darsih dkk (2012), Semakin baik ketahanan struktur granula pati maka akan menyebabkan semakin banyak kandungan air yang diserap oleh molekul molekul pati dari tepung maka menyebabkan filtrat (supernatant) yang didapatkan setelah mengalami proses pemisahan akan cendrung semakin berkurang. Selain itu penurunan solubillitas ini juga dikaitkan dengan kandungan amilosa pada tepung yang semakin meningkat seiring dengan meningkatnya konsentrasi STPP yang digunakan. Chang et al. dalam Darsih dkk (2012), juga menjelaskan mengenai hubungan antara penurunan daya solubilitas pati dengan tingkat kandungan amilosa bahan tersebut. Kelarutan pati beras yang rendah dapat disebabkan oleh keberadaan amilosa tergolong tinggi sehingga yang dapat membatasi daya kelarutan (solubilitas) pati yang disebabkan oleh ketahanan struktur granula pati selama pemanasan dengan air.

Berdasarkan hasil uji anova sebelumnya, diketahui bahwa adanya pengaruh tidak hanya dihasilkan oleh variasi konsentrasi STPP, tapi juga variasi lama waktu reaksi yang diberikan. sehingg perlu dilakukan uji lanjutan (uji Duncan) dengan tujuan untuk mengetahui tingkat pengaruh yang dapat disimpulkan dari tingkat kesamaan hasil solubilitas sempel.

Berdasarkan Duncan, variasi waktu menunjukan pengaruh daya solubilitas sempel akan semakin menurun seiring dengan semakin lamanya direndam dalam larutan senyawa
ISSN: $2443-1095$

fosfat, dan paling rendah dihasilkan oleh sempel yang direndam selama 1 jam. Perendaman selama 1,5 jam ternyata solubilitas tepung kembali mengalami peningkatan

Beberapa kandungan amilosa pati dari tepung ubi jalar yang telah mengalami penyerapan air optimum pada perendaman selama 1 jam. Retnaningtyas dkk (2014), melaporkan hal yang sama yaitu hasil solubillitas tepung yang dimodifikasi dengan STPP akan cendrung meningkat setelah pati melewati titik jenuhnya. Sedangkan jika direndam lebih lama lagi maka molekul amilosa akan mengalami proses pemecahan molekul akibat kelebihan kapasitas menyerap air sehingga air hasil dari proses pemecahan beberapa molekul ini akan keluar dan mengakibatkan jumlah supernatan (filtrat) yang dihasilkan setelah melewati proses pemisahan akan cendrung meningkat.

Menurut Retnaningtyas dkk (2014), peningkatan nilai solubillitas ini dikarenakan adanya proses pemecahan molekul amilosa pada ikatan hidrogen maupun pada ikatan fosfat. Kandungan amilosa yang telah mengalami proses pemecahan akan keluar dan larut didalam air, yang juga menyebabkan meningkatnya jumlah daya solubilitas tepung (Chandra dkk 2013).

Solubilitas pati tepung pada perlakuan konsentrasi yang sama dengan dikombinasikan dengan proses reaksi selama 30 menit cendrung lebih tinggi dibandingkan dengan daya solubilitas perlakuan lainnya. Hal ini sesuai dengan pendapat Hee-Joung an dalam Pudjihastuti (2010), yang menjelaskan bahwa daya swelling power tepung sangat dipengaruhi oleh lama waktu perendaman, yaitu semakin lama waktu perendaman akan menyebabkan semakin lama hidrolisis, menyebabkan rantai pati tereduksi. Akhirnya rantai pati cenderung lebih pendek dan mudah menyerap air. Matsuguma dalam Budiyati (2016) menjelaskan bahwa Kelarutan pati sangat tergantung pada nilai kadar amilosa dan kemudahannya untuk keluar dari butir pati, yaitu kelarutan suatu bahan berupa tepung dalam air dipengaruhi oleh seberapa besar jumlah kandungan fraksi 
Versi Online:

http://www.profood.unram.ac.id/index.php/profood e-ISSN: 2443-3446

amilosa yang terlepas dari rantai pati dan larut dalam air (supernatant).

\section{KESIMPULAN}

Modifikasi crosslink mampu meningkatkan daya serap air dan nilai swelling power (daya kembang). Akan tetapi tepung modifikasi ini memiliki kelarutan (solubillitas) yang lebih rendah daripada tepung ubi jalar alami. Modifikasi tepung ubi jalar memiliki batas optimum penyerapan serta pengembangan optimal pada reaksi selama 1 jam dengan konsentrasi STTP 3\%.

\section{UCAPAN TERIMA KASIH}

Penulis mengucapkan terimaksih atas bentuan semua pihak yakni Dosen Pembimbing, Pihak Dekanat dan Laboran. Tidak lupa disampaikan salalam hormat pada orang tua serta salam kompak untuk kawankawan THP angkatan 2013.

\section{DAFTAR PUSTAKA}

Amin, N.A. 2013. Pengaruh Suhu Fosforilasi Terhadap Sifat Fisikokimia Pati Tapioka Termodifikasi. Skripsi. Fakultas Pertanian. Universitas Hasanudin. Makasar.

Budiyati.C.S, A.C Kumoro, Ratnawati, D.S. Retnowati. 2016. Modifikasi Pati Sukun (Artocarpus altilis) dengan Teknik Oksidasi Menggunakan Hidrogen Peroksida Tanpa Katalis. Jurnal Teknik 37: 32-40.

Damodaran,S., J.E. Kinsella. 1982. Effect of Conglycinin On Thermal Aggregation of Glycinin. Tesis. Institut Teknologi Bandung. Bandung

Darsih, C., Miftakhussolikhah, D. Ariani. Angwar.M, Haryadi. 2012. Karakteristik Sifat Fisik Dan Kimia Tepung Kentang Hitam (Coleus tuberosum) Desa Mertelu, Kecamatan Gedangsari, Kabupaten Gunungkidul. Proceeding Seminar IImu Pengetahuan Teknik. Bandung. ISSN 2303-0798.

Dewi, S.K. 2008. Pembuatan Produk Nasi Instan Berbasis Fermented Cassava Flour sebagai Bahan Pangan Alternatif. Skripsi. Institut Pertanian Bogor.
Pro Food (Jurnal Ilmu dan Teknologi Pangan)

Vol 5 No. 1 Mei 2019

ISSN: 2443-1095

Hendy. 2007. Formulasi Bubur Instan Berbasis Singkong Sebagai Pangan Alternatif. Skripsi. Institut Pertanian Bogor.

Honestin, T. 2007. Karakterisasi Sifat Fisikokimia Tepung Ubi Jalar (Ipomoea batatas). Skripsi. Institut Pertanian Bogor. Bogor.

Kalsum, N dan Surfiana. 2013. Karakteristik Dekstrin dari Pati Ubi Kayu yang Diproduksi dengan Metode Pragelatinisasi Parsial. Jurnal Penelitian Pertanian Terapan 13(1).

Kristiyani, M.W.E. 2012. Pemanfaatan Tepung Ubi Ungu dalam Pembuatan Produk Patiseri. Skripsi. Fakultas Teknik Universitas Negeri Yogyakarta. Yogyakarta.

Lensun, C.I.J, E.J.N Nurali, T.M Langi, dan J.E.A Kandow. 2013. Pemanfaatan Sagu Baruk (Arenga microcarpa) dengan Ubi Jalar Ungu (Ipomoea batatas) dalam Pembuatan Mie Basah. Jurnal Fakultas Pertanian UNSRAT 3(6).

Mandasari, R., B.S Amanto, A.A. Ridwan. 2015. Kajian Karakteristik Fisik, Kimia, Fisikokimia dan Sensori Tepung Kentang Hitam (Coleus tuberosus) Termodifikasi Menggunakan Asam Laktat. Jurnal Teknosains Pangan 4.

Marta. H, dan Tensiska. 2016. Kajian Sifat Fisikokimia Tepung Jagung Pragelatinisasi Serta Aplikasinya Pada Pembuatan Bubur Instan. Jurnal Penelitian Pangan 1(1).

Naim, I.E. 2016. Kajian Substitusi Tepung Terigu dan Tepung Ubi Jalar Ungu Berkadar Pati Resisten Tinggi Terhadap Kualitas Muffin. Skripsi. Universitas Lampung. Lampung.

Pudjihastuti, I. 2010. Pengembangan Proses Inovatif Kombinasi Reaksi Hidrolisis Asam dan Reaksi Photokimia UV Untuk Produksi Pati Termodifikasi dari Tapioka. Tesis. Pascasarjana Teknik Kimia. Universitas Diponegoro. Semarang.

Retnaningtyas, D.A., dan W.D.R. Putri. 2014. Karakterisasi Sifat Fisikokimia Pati Ubi Jalar Oranye Hasil Modifikasi Perlakuan STPP (Lama Perendaman dan Konsentrasi). Jurnal Pangan dan Agroindustri 2(4): 68-77. 
Rohajatien, U. 2010. Studi Tentang

Pemrosesan Tepung Sorgum

Terfosforilasi dan Aplikasinya Pada Berbagai Adonan Pastri. Jurnal Teknologi dan Kejuruan 33(1): 93-106.

Setyowati, A. 2010. Penambahan Natrium Tripolifosfat dan CMC (Carboxy Methyl Cellulose) Pada Pembuatan Karak. Jurnal Agrisains 1(1).

Triyono, A. 2010. Mempelajari Pengaruh Penambahan Beberapa Asam Pada Proses Isolasi Protein Terhadap Tepung Protein Isolat Kacang Hijau (Phaseolus Radiatus L.). Seminar Rekayasa Kimia dan Proses, 4-5 Agustus. Semarang.

Widhaswari, V.A., dan W.D.R. Putri. 2014. Pengaruh Modifikasi Kimia dengan STTP Terhadap Karakteristik Tepung Ubi Jalar Ungu. Jurnal Pangan dan Agroindustri 2 (3): $121-128$

Widyasaputra, R. dan S.S. Yuwono. 2013. Pengaruh Fermentasi Alami Chips Terhadap Sifat Fisik Tepung Ubi Jalar Putih (Ipomoea batatas) Terfermentasi. Jurnal Pangan dan Agroindustri 1(1): 7889. 